Goldschmidt 2021 Abstract

https://doi.org/10.7185/gold2021.6807

\section{Time for an upgrade: the importance of weathering for increasing ore tenor in carbonatite complexes}

\author{
PAUL SLEZAK ${ }^{1,2}$, MANDI HUTCHINSON ${ }^{3}$, CARL $^{2}$ \\ SPANDLER $^{4,5}$, MURRAY W. HITZMAN ${ }^{2,3}$ AND RICHARD \\ WENDLANDT ${ }^{3}$ \\ ${ }^{1}$ University College Dublin \\ ${ }^{2}$ iCRAG - Irish Centre for Research in Applied Geosciences \\ ${ }^{3}$ Colorado School of Mines \\ ${ }^{4}$ James Cook University \\ ${ }^{5}$ The University of Adelaide \\ Presenting Author: paul.slezak@ucd.ie
}

Carbonatites are igneous rocks comprising $>50 \%$ primary carbonate minerals and often exceptional REE-bearing minerals, making them important sources for critical metals. Primary critical metal-bearing carbonatites may or may not have the appropriate metal endowment to be economic. However, those that have undergone weathering often exhibit increased ore tenor.

Carbonatite critical metal enrichment typically occurs through lateritisation, especially in humid tropical environments (e.g., Gifford Creek, Western Australia), but also in more temperate humid to semi-arid environments (e.g., Bear Lodge, Wyoming). The environmental conditions and the underlying mineralogy of the critical metal phase are important as many REE-bearing minerals, especially REE(fluor)carbonates, are broken down under meteoric conditions, freeing REE.

The Bear Lodge carbonatite deposit contains 16.3 million tonnes of $3.05 \%$ TREO hosted in a suite of REE(fluor)carbonate minerals. The Bear Lodge carbonatite's exposure to temperate conditions during the Paleogene resulted in weathering, generating up to $\sim 50 \%$ porosity and upgrading the ore tenor $\sim 2-3$ times in zones of moderately weathered carbonite. The REE concentration in these moderately weathered zones was mainly increased via material removal as only small-scale supergene REE-mobilisation was observed in this zone. However, intensely weathered zones experienced more remobilisation where primary REE-bearing minerals, like ancylite $\left[\operatorname{REESr}\left(\mathrm{CO}_{3}\right)_{2}(\mathrm{OH}) \cdot \mathrm{H}_{2} \mathrm{O}\right.$, were altered to parisite-synchysite $\mathrm{Ca}(\mathrm{REE})_{2}\left(\mathrm{CO}_{3}\right)_{3} \mathrm{~F}_{2}$ $\left.\mathrm{Ca}(\mathrm{REE})_{2}\left(\mathrm{CO}_{3}\right)_{2} \mathrm{~F}\right]$, cerianite $\left.\left[\mathrm{Ce}^{4+}, \mathrm{Th}\right) \mathrm{O}_{2}\right]$, and other REE-rich phases.

The Gifford Creek Carbonatite Complex (GCCC) in Western Australia contains 21 million tonnes of $1.17 \%$ TREO occurring as monazite $\left[\operatorname{REE}\left(\mathrm{PO}_{4}\right)\right]$ in vuggy "ironstones". Humid conditions during the Paleogene in Western Australia created suitable conditions for meteoric water to infiltrate and alter the ferrocarbonatite to ironstone. This weathering dissolved and removed the primary carbonate mineralogy, concentrating the REE by $\sim 2-10$ times. The ferrocarbonatite and ironstone have similar normalised REY patterns, suggesting little fractionation among the REE. The lack of REE mobility in the GCCC is attributed to the abundance of monazite and its immobility under meteoric conditions compared to apatite or REE(fluor)carbonates. The immobility of monazite and passive ore upgrade in the GCCC is more closely related to the eluvial processes observed in the moderately weathered carbonatite at Bear Lodge, rather than the complex REE-remobilisation documented in the intensely weathered zones. 